\title{
Effects Of Auditors' Culpability On Creative Accounting In Southwest Nigeria
}

\author{
Ojuolape Tunde Charles (Ph.D) \\ Department of Accounting, Faculty of Management Sciences, \\ Ekiti State University, PMB 5363, Ado-Ekiti, Nigeria. \\ Tony Mofehintolu Akinnola \\ Department of Accounting, \\ Faculty of Social \& Management Sciences, \\ Adekunle Ajasin University , PMB 001, Akungba Akoko, Ondo State. Nigeria.
}

\begin{abstract}
The study examined the effects of auditors' culpability on creative accounting in Southwest Nigeria. The study employed questionnaire to gather data from 66 managers and 66 accountants. The study was analysed with the use of descriptive statistics and One Way Analysis of Variance to test the hypotheses of the study. The study found that auditors' culpability has no effect on creative accounting in private sector in Nigeria. The study revealed that that the reasons for statutory auditors engaging in creative accounting practices have effect on the practice of creative accounting in Nigeria. The study recommends that accountants should uphold high ethical standards and maintain integrity in all their professional dealings. Accountants should not allow personal prejudice or bias to override the principle of objectivity, transparency and due diligence in the profession. Auditors must not only develop questioning mind, skill for critical assessment of audit evidence but must also exercise these skills with reasonable care and diligence.
\end{abstract}

Keywords: Creative Accounting, Private Sector, Accountant, Auditors, Objectivity

\section{INTRODUCTION}

The managers of business are obliged to report to the owners on how their business has been managed. The owners will like to assure themselves that the report contains no errors, it is not misleading and it discloses all relevant information. A way out of this problem of credibility in financial accounts and reporting is to appoint an independent person, known as auditor, to investigate the report and express his opinion on it. The auditor do not only has a responsibility to the shareholders, he also has a duty of care, skill and diligence to third parties. The statutory auditors are the essential fulcrum upon which the concepts of objectivity, fairness, independence and integrity of financial reporting rest (Adeyemi, 2004).

However, companies have a great deal of discretion in choosing accounting principles that impact on their reported financial results and positions. Generally Accepted Accounting Principle (GAAP) controls the amount of discretion that company has in preparing financial statement. These guiding principles are sometimes stretched to the limit or even ignored. Management may have many competing motivation that drive their choice of accounting policies. Ijeoma and Aronu (2013) viewed creative accounting as the aggressive use of choices available under accounting rules, to present the most fattening view of a company possibly in its financial statement. Okoye and Alao (2008) defines creative accounting as an accounting practices that tend to circumvent, albeit, cleverly, or manipulate the rules of standard accounting practices or the spirit of those values. They are characterized by dubious complication and use of 'novel' ways of presenting income, assets or liabilities. 
Bakre (2007) argues that accounting professionals have increasingly used their expertise to conceal and promote anti-social practices. For example Akintola Williams and Deloitte were indicted for facilitating the falsification of accounts of Afribank PLC (Main Street Bank PLC) and for deliberately overstating the profits of Cadbury Nigeria PLC. The collapse of intercontinental bank plc; Ile-oluji Cocoa Products Company Limited; Standard Printing and Publishing Company; African Petroleum and Union Dicon Salt have been linked to creative accounting practices by management in connivance with the Auditors.

According to Adeyemi (2004) noted that there is a general opinion that modern day Nigerian Accountants are mere tools in the hands of perpetrators of fraud, and that they simply allow personal interest to override their national call to duty. The high rate of creative accounting challenges in Nigeria can not be over emphasized. The nation is sadly at the other side of economic development due to this practices. In Nigeria, the spate of corporate failure witnessed mostly in the financial sector in early 1990's brought auditors into focus and caused the Nigerian to question the roles of auditors.

Notwithstanding, past studies on creative accounting, such as, Domash (2002); Ijeoma and Aronu (2013) have focused mainly on the impact of creative accounting on investors' decisions in the stock market without highlighting the reasons for such practices. Equally, these studies were of foreign origin and their findings may not be suitable for Nigeria considering environmental differences. Most of the available studies in Nigeria, such as, Osisioma and Enahoro (2006), Okoye and Alao (2008), Akenbor and Ibanichuka (2012), Aremu and Bello (2004) and Idris, Kehinde, Ajemunigbohun and Gabriel (2012) concentrated their works on the nature, techniques, motives, effects, detection and prevention of creative accounting with emphasize on the private sector of the economy. These studies did not give consideration to the effects of auditors' culpability on creative accounting. Hence, it is against this back drop that the study seeks to ascertain whether auditors' culpability leads to reduction in creative accounting in South West Nigeria. It will equally provide essential findings to assist policy makers in formulating and administering relevant policies to minimize the spate of creative accounting by enhancing audit quality in Nigeria private sector. The broad objective of the study is to examine the effects of auditors' culpability on creative accounting in Southwest Nigeria. The specific objectives for the study are to:

- assessed the rationales for statutory auditors to engage in creative accounting practices.

- examined the various ways in which creative accounting can be undertaken in financial reporting.

\section{Creative accounting}

\section{LITERATURE REVIEW}

Creative accounting is not a new phenomenon. The practices of creative accounting started since the industrial revolution and continued up to these days, but these practices increased since the starting of 1980s of the previous century. Creative accounting is the transformation of financial accounting figures from what they actually are to what preparers' desire by taking advantage of the existing rules and/or ignoring some or all of them (Bolkaoui, 2004). Several terms appeared to express the notion of creative accounting and these include: accounting manipulation, fraudulent reporting, income smoothing, earnings management, disclosure management, earning smoothing, financial engineering, window dressing and cosmetic accounting.

Rosner (2003) mentions that accounting manipulation and fraudulent act are two similar terms that represent management intent to interfere with the measurement and disclosure of 
accounting transactions and items of the financial statements, even though the accounting standards do not permit these practices. Rosner also mentioned that earnings manipulation is a studied selection methods of the operating, financing, and investing operations. Moreover, he mentioned that such selection of accounting methods and policies are permitted by accounting standards, so this selection should be disclosed to users. Bolkaoui (2004), opines that creative accounting is the process of converting accounting numbers from its actual value towards a desired value by management, whereas, income smoothing is an intended smoothing of the announced number of income by management in order to decrease the variations in income from period to period, therefore, income appears at its normal amount. Creative accounting is perceived as a transformation from actual to in actual announced information. Based on these definitions, we see that creative accounting is a process where management attempts to transform actual financial information to incorrect information in order to satisfy the objectives of managements.

\section{Auditor's culpability}

An auditor is not infallible. He is human. This is why the law cannot hold him responsible for pure errors of judgment. However, Auditor's culpability refers to that situation where the auditor is held responsible for his act of omission or commission while carrying out his professional duty. The External Auditor by law, shares a special fiduciary relationship with the company that he audits its books of accounts. The liabilities of the auditor can be seen to be of two kinds: Liability under common law; Liability under statute.

This can be diagrammatically illustrated thus:

Figure 1: Diagram On Auditor's Liability - Legal Structure

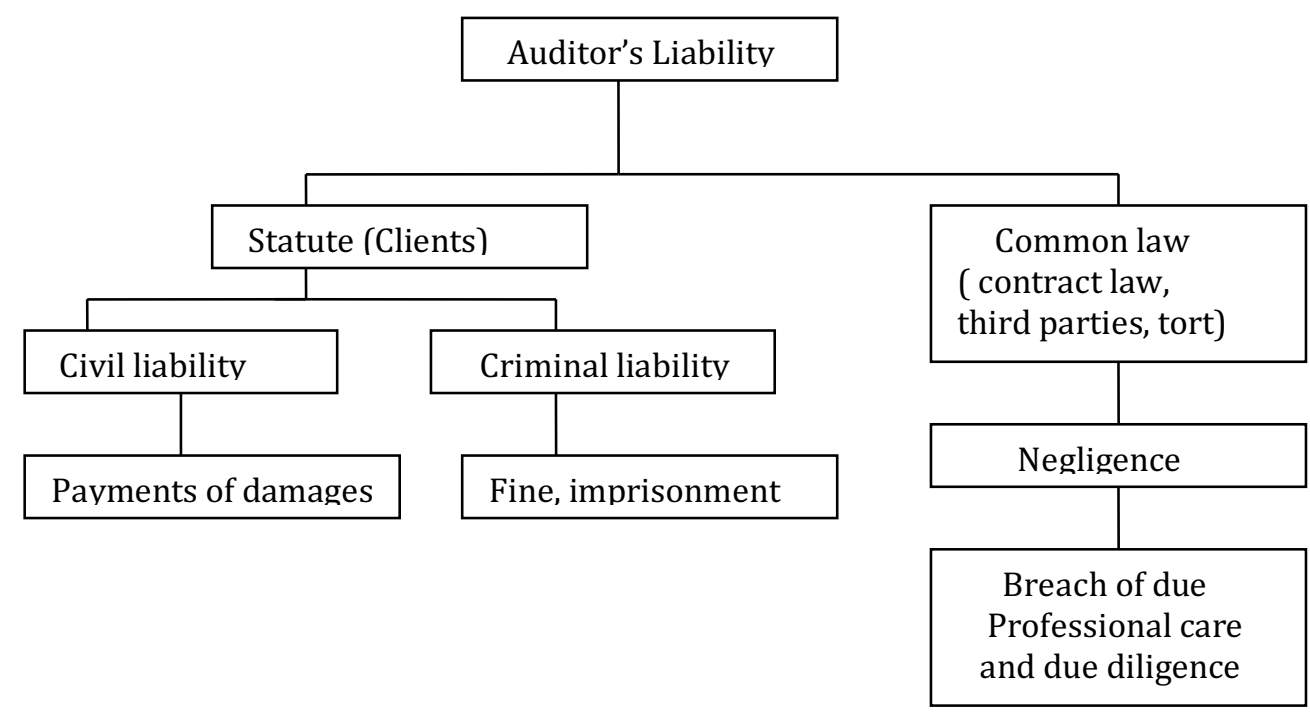

Source: Authors Design (2019)

In the diagram, Common law involves civil liabilities such as breach of contract and the tort of misfeasance against a client, and liability to third parties. Under statutes, we have criminal liabilities as provided by legislation such as CAMA, 2004, the Criminal Code (applicable in the Southern states in Nigeria) or the Criminal Procedure Code (applicable in the Northern states in Nigeria) and under the various tax laws with penal provisions. Also, liability under statute can arise from the provisions of Securities and Exchange Commission (SEC) rules, and the Investments and Securities Act (ISA) 2007. Under the statutes, an Auditor may also be 
criminally liable where he, in his report to a company makes a statement, which is false, knowing that the statement is false.

\section{Rationales for statutory auditors to engage in creative accounting practices}

The followings are some of the rationales behind auditors been involved in creative accounting practices:

i. Weak stance of the professional bodies: Bakre (2007) argued that the reluctance of professional bodies to either investigate or discipline appropriately their erring members has contributed to ever-increasing involvement of professional accountants and auditors in creative accounting practices in Nigeria.

ii. Weak posture of regulatory bodies: The weak monitoring, regulation, privacy, nonsubjecting of auditors reports and auditing firms to external scrutiny has enhanced their involvement in creative accounting practices in Nigeria. The regulatory framework in Nigeria is weak because members of the professional firms implicated in a number of anti-social practices in Nigeria were not adequately sanctioned (Okike, 2004; Bakre, 2007)

iii. Societal factors: The capitalist society in which the accountants operate, arguably shape and allow them to engage in accounting information manipulation practices (Okike, 2004; and Otusanya and Lauwo, 2010). Under capitalist pressures auditors has repeatedly sacrificed ethical norms for financial gains. In Nigeria, Adeyemi (2004) opined that the socio-economic, political and cultural environment of Nigeria has facilitated the involvement of accountants and auditors in unethical and sharp practices and other professional misconducts in the political directorate, public service and corporate Nigeria.

iv. Increase in income: Bakre (2007), observed that the ambition of many professionals (such as accountants and auditors) serving in both public and private sectors is to increase their earnings, hence they involve in unethical practices.

v. Survival: in order to survive, accounting firms have been transformed into fiercely competitive businesses seeking to penetrate and expand markets for all kinds of business services where the trappings of professionalism seem increasingly remote and irrelevant. In order to survive in the modern competitive Nigeria accountancy market environment therefore, accountants tend to retain their client interest (such as, cooking the book, tax evasion and avoidance schemes) at the expense of the public interest they profess to protect.

vi. Lapses in the available financial standards and regulations: There are general inconsistencies, lack of uniformity and clarity in the regulations guiding financial reporting and compliance is not strictly monitored. Obazee (2005) remarked that because there was no stringent monitoring in Nigeria, many significant accounting and reporting inadequacies and departure from norms have passed unnoticed.

vii. Weak penalties: The penalties for offences committed are no longer relevant, they are too small that companies can decide to commit the offence and pay the fine. Such fines could not serve as deterrent but rather an encouragement for their involvement in unethical practices.

viii. Weak financial systems: Weak financial system that is, institutional and accounting system and controls have created the enabling environment for the accountants to become collaborators and sometimes the real perpetrators of abuse, corruption and fraud in the national financial system (Mantu, 2005).

ix. Innate psychological imbalance: Some auditors have an innate psychological imbalance which often manifest in tendencies to be anti-social (Akin Ogundeji, 2010). 
x. Summarily, Aloba (2002) confessed that professional accountants have become instruments of siphoning money and so professional ethics were thrown down the drains while integrity and honour paved way for materialism and professional turgidity.

\section{Empirical framework}

Rabin (2003) studied the determinants of auditors' attitudes towards creative accounting. In more details, the study investigates whether there is relationship between auditors' attitudes towards creative accounting and their ethical judgment. In addition, the author also investigates the relationship between auditors' attitudes and their evaluation of the quality of financial reporting and their perception of factors that influence preparers of financial statements to use aggressive accounting techniques. The study finds that a significant relationship exists between auditors' assessment of the relevance and reliability of reported information and their attitudes towards creative accounting. Moreover, the study gained some insight into auditors' perceptions of the factors that influence preparers for the use of creative accounting in South Africa.

Marianne, (2006) carried out a study to determine the importance of audit independence to the external auditors' role in banking regulation and supervision. In addition, the study investigates the factors which may threaten auditors' independence. The study finds that despite the support of the dual role of the reporting accountants and external auditors, independency of auditors is still questionable because both roles of auditor and accountant are separate and the external auditors perform non-audit services. As a result, more safeguards should be in place in relation to the dual roles of the external auditor and accountant, and more alternatives should be provided before the role of reporting accountant is taken as means of last resort. Moreover, the study reveals that mandatory rotation of auditors may be detrimental, and a cost-benefit analysis of this mandatory rotation is necessary before the decision to implement, or not, is taken. In addition, the study reveals that auditors should be held more accountable for negative consequences of their actions towards the third party. At end, the study recommends more works to be carried out regarding auditor's liability.

Moldovan, Achim, and Avram, (2010) studied the roles of creative accounting as a technique of accounts manipulation in contrast with the fair view presentation, and the ethics of accounting profession. In this study, the authors reviewed the opinions of different authors on the subject while contrasting both fraud and professional ethics with creative accounting. In addition, they explained the inverse casual relationship between creative accounting and fair view principle. The study reviewed the writings of other authors regarding creative accounting in order to find or recommend some solutions to this problem which threaten the fair presentation. The recommended solutions in this area are related to accounting rules and professional accounting ethics. These solutions are characterized with its practicability and can be put in practice by the company itself and by other interested users.

Matar and Al Halabi, (2009) investigated the roles that auditors can play in restricting creative accounting and its effect on the reliability of accounting information. The purpose of the study is to identify the used methods in creative accounting practices and its effects on the reliability of accounting information, and to determine management's incentives behind its exercise to these practices. Other important goals of the study are to identify the roles that auditors play in detecting and restricting the practices of creative accounting that occurred by the shareholding Jordanian companies. The study finds that the followed methods in practicing creative accounting affect the reliability of announced accounting information by the above mentioned type of Jordanian companies. In addition, the study finds that management practice different 
methods to exercise creative accounting, but auditors take the required procedures and tests to detect these practices.

Dahdouh, (2006) carried out a related study to the subject of creative accounting and the role of auditors in this issue. The study objects for determining the problem of fraudulent in financial statements, and to identify the factors that determine its detection following to failure in several large corporations all over the world. The study focused on the roles of auditors in detecting fraudulent practices in Jordan. He finds that there are several factors associated with auditors, and other factors associated with the firm, can help in detecting fraudulent act in financial statements. The most important conclusion of the study is that auditors' ability in detecting fraudulent act in financial statements is influenced by different associated factors with the issuances of these companies.

\section{Population and Sample}

\section{METHODS}

The population of the study comprises of 210 managers and accountants in the selected states- Lagos, Ondo, and Oyo with 70 questionnaires per each state. Out of the population of 210 (comprising 105 managers and 105 accountants in Lagos, Ondo, and Oyo), 138 respondents were administered questionnaire. The formula used to arrive at the sample size of 138 was that of Yaro Yamane's:

$$
\mathrm{n}=\frac{\mathrm{N}}{1+\mathrm{N}(\mathrm{e})^{2}}
$$

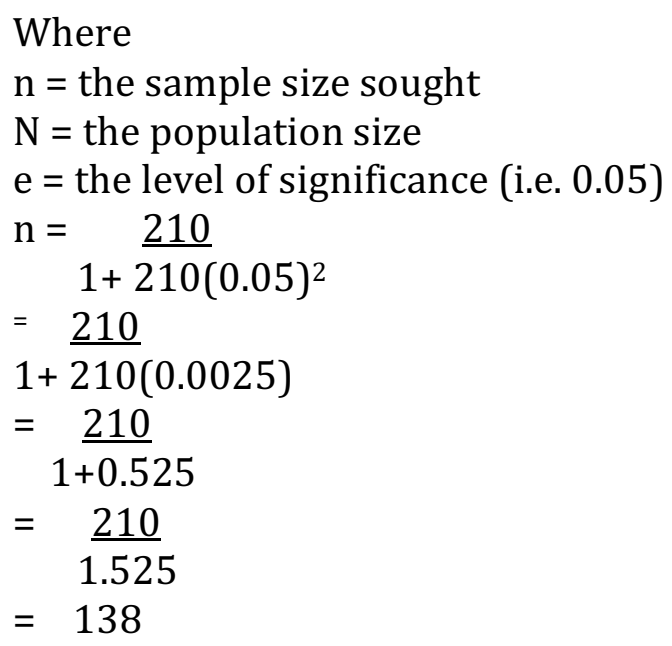

Random sampling was used in administering questionnaire to the two groups of respondentsaccountants and managers. Out of the 138 questionnaires administered only 132 questionnaires were returned representing $95.65 \%$ of the administered questionnaires.

\section{Method of data collection}

Questionnaire was used to elicit information from the respondents. A structured questionnaire was administered by hand to the respondents. The questionnaire was divided into two sections (sections 1-2). The first section contains questions relating to the respondents' biodata. The second section contains questions that will enable the researcher generate data for the testing of the stated hypotheses. The respondents were made to indicate in the questionnaire the extent they agree or disagree with the stated problems. 


\section{Method of data presentation and analysis}

The study used descriptive statistics and One-way Analysis of Variance (ANOVA) statistical technique to test the study hypotheses.

\section{ANALYSIS AND INTERPRETATION OF RESULTS}

Table 1: Respondents' bio-data

\begin{tabular}{|c|c|c|c|}
\hline VARIABLES & DESCRIPTION & FREQUENCY & \%AGE \\
\hline \multirow[t]{3}{*}{ Sex } & Male & 85 & 64.39 \\
\hline & Female & 47 & 35.61 \\
\hline & Total & 132 & 100 \\
\hline \multirow[t]{6}{*}{ Age } & Less than 30 years & 14 & 10.61 \\
\hline & 30 and less than 40 years & 26 & 19.70 \\
\hline & 40 and less than 50 years & 44 & 33.33 \\
\hline & 50 and less than 60 years & 30 & 22.73 \\
\hline & 60 years and more & 18 & 13.63 \\
\hline & Total & 132 & 100 \\
\hline \multirow[t]{3}{*}{ Respondent Post } & Manager & 66 & 50 \\
\hline & Accountant & 66 & 50 \\
\hline & Total & 132 & 100.0 \\
\hline \multirow[t]{6}{*}{$\begin{array}{l}\text { Educational } \\
\text { Qualification }\end{array}$} & $\begin{array}{l}\text { Lower than Bachelor } \\
\text { Degree }\end{array}$ & 15 & 11.36 \\
\hline & Bachelor Degree & 60 & 45.45 \\
\hline & Master Degree & 20 & 15.15 \\
\hline & PhD Degree & 7 & 5.30 \\
\hline & Professional Certificate & 30 & 22.74 \\
\hline & Total & 132 & 100 \\
\hline \multirow[t]{6}{*}{ Years of Experience } & Less than 5 years & 10 & 7.58 \\
\hline & 5 and less than 10 & 19 & 14.39 \\
\hline & 10 and less than 15 & 56 & 42.42 \\
\hline & 15 and less than 20 & 33 & 25.00 \\
\hline & 20 and less than 25 & 14 & 10.61 \\
\hline & Total & 132 & 100 \\
\hline
\end{tabular}

Source: Field Survey, 2019.

From the table above, $64.39 \%$ of the respondents were males, while most respondents are male (85), while $35.61 \%$ of the respondents were female. Auditing is a field profession, so it is more appropriate to male people than female. Regarding respondents' age, table 4.1 shows that $10.61 \%$ of respondents are less than 30 years old, $33.33 \%$ of respondents are 40 and less than 50 years old. The table shows that $89.39 \%$ of total respondents are 30 or more years old. The table shows that $88.64 \%$ of total respondents have bachelor or higher qualifications, so only $11.36 \%$ of them have less than bachelor degree. This piece of information is an advantage for the research because when most respondents have enough qualifications, they will have good ability to understand the items of the questionnaire, and have more ability to provide reasonable responses to these items. The table shows that just $7.58 \%$ of respondents have less than 5 years-experience, $92.42 \%$ of these respondents have more than 5 years-experience and most respondents have 10 to 20 years-experience.

\section{Test of hypotheses}

\section{Auditors' culpability and creative accounting in Nigeria}

Ho1: Auditors' culpability has no effect on creative accounting practices in private sector in Nigeria. 
Table 2: Descriptive 95\% Confidence interval for Mean

\begin{tabular}{|c|c|c|c|c|}
\hline & N & Mean & $\begin{array}{c}\text { Standard } \\
\text { Deviation }\end{array}$ & Standard Error \\
\hline SA & 5 & 32.4 & 14.381 & 6.431 \\
\hline A & 5 & 31.2 & 11.841 & 5.295 \\
\hline D & 5 & 27.0 & 3.742 & 1.673 \\
\hline SD & 5 & 25.8 & 9.011 & 4.030 \\
\hline U & 5 & 15.6 & 1.517 & 0.678 \\
\hline
\end{tabular}

Source: Field Survey, 2019.

Table 3: Analysis of Variance (Anova)

\begin{tabular}{|c|c|c|c|c|c|}
\hline Source & $\begin{array}{c}\text { Sum of } \\
\text { Square (SS) }\end{array}$ & $\begin{array}{l}\text { Degree of } \\
\text { Freedom } \\
\text { (df) }\end{array}$ & $\begin{array}{c}\text { Means } \\
\text { Square (Ms) }\end{array}$ & F (Ratio) & Remark \\
\hline $\begin{array}{l}\text { Variance } \\
\text { between the } \\
\text { means }\end{array}$ & $\mathrm{SS}_{\mathrm{B}}=881.99$ & $K-1=4$ & $\begin{array}{l}\mathrm{SS}_{\mathrm{B}} / \mathrm{df}_{\mathrm{B}} \\
=220.50\end{array}$ & \multirow{3}{*}{$\begin{array}{l}\mathrm{MS}_{\mathrm{B}} \\
\mathrm{MS}_{\mathrm{w}} \\
=2.4803\end{array}$} & \multirow{3}{*}{$\begin{array}{l}\text { Accept } \\
\text { Or } \\
\text { Reject }\end{array}$} \\
\hline $\begin{array}{l}\text { Variance within } \\
\text { the means }\end{array}$ & $\mathrm{SS}_{\mathrm{W}}=1778$ & $\mathrm{~N}-\mathrm{k}=20$ & $\begin{array}{l}\mathrm{SS}_{\mathrm{W}} / \mathrm{df}_{\mathrm{w}} \\
=88.90\end{array}$ & & \\
\hline Total & $\mathrm{SS}_{\mathrm{T}=2660}$ & $N-1=24$ & & & \\
\hline
\end{tabular}

Source: Data Analysis, 2019.

From the SPSS descriptive table above, it was discovered that five (5) questions were inputted in section 2 of the questionnaire. It was observed that 32.4 being the highest mean value on the descriptive table, but the least standard deviation was 1.517, this reflected that table shows, the respondents reaction to the questions posted to be indifference (not sure). Table 3 shows that the F-calculated resulted to 2.4803 at degree of freedom of 4 and 20 with $95 \%$ confidence/significance level ( 0.05 alpha) while, the F-distribution table shows 2.87 values.

Decision: Since the calculated F-value of 2.4803 is less than the F- tabulated value of 2.87 , the null hypothesis is accepted, which means that auditors' culpability has no effect on creative accounting in private sector in Nigeria.

\section{Auditors engaging in creative accounting practices and the practice of creative accounting in Nigeria}

Ho2: The reasons for statutory auditors engaging in creative accounting practices have no effect on the practice of creative accounting in Nigeria.

Table 4: Descriptive 95\% Confidence interval for Mean

\begin{tabular}{|c|c|c|c|c|}
\hline & N & Mean & $\begin{array}{c}\text { Standard } \\
\text { Deviation }\end{array}$ & Standard Error \\
\hline SA & 5 & 35.20 & 15.912 & 7.116 \\
\hline A & 5 & 34.20 & 8.408 & 3.760 \\
\hline D & 5 & 29.00 & 6.205 & 2.775 \\
\hline SD & 5 & 22.40 & 7.301 & 3.265 \\
\hline U & 5 & 11.20 & 0.837 & 0.374 \\
\hline
\end{tabular}

Source: Field Survey, 2019. 
Table 5: Analysis of Variance Table

\begin{tabular}{|l|l|l|l|l|l|}
\hline Source & $\begin{array}{l}\text { Sum of } \\
\text { Square (SS) }\end{array}$ & $\begin{array}{l}\text { Degree of } \\
\text { Freedom (df) }\end{array}$ & $\begin{array}{l}\text { Means } \\
\text { Square (Ms) }\end{array}$ & F (Ratio) & Remark \\
\hline $\begin{array}{l}\text { Variance } \\
\text { between the } \\
\text { means }\end{array}$ & 1960.40 & 4 & 490.10 & 5.8850 & Accept \\
\cline { 1 - 1 } $\begin{array}{l}\text { Variance } \\
\text { within the } \\
\text { means }\end{array}$ & 1665.60 & 20 & 83.28 & Or \\
\hline Total & $\mathbf{3 6 2 6 . 0 0}$ & $\mathbf{2 4}$ & & & \\
\hline
\end{tabular}

Source: Data Analysis, 2019.

From the SPSS descriptive table above, it was discovered that five (5) questions were inputted in section 2 of the questionnaire. It was observed that 35.20 being the highest mean value on the descriptive table, but the least standard deviation was 0.837 , this reflected that table shows, the respondents reaction to the questions posted to be indifference (not sure). The table shows that the F-calculated resulted to 5.8850 at degree of freedom of 4 and 20 with $95 \%$ significance level ( 0.05 alpha) while, the F-distribution table shows 2.87 values.

Decision: Since the calculated F-value of 5.8850 is greater than the F- tabulated value of 2.87, the null hypothesis is rejected, which means that the reasons for statutory auditors engaging in creative accounting practices have effect on the practice of creative accounting in Nigeria.

\section{DISCUSSION OF FINDINGS}

The study reveals creative accounting exists in published financial statements and annual reports of companies in Nigeria and the practice is considered by stakeholders as bad and meant to deceive or take advantage of users of the financial statements. The researcher undertook a study to observe whether or not there exist any statistical effects of Auditors' culpability on creative accounting. The F-ratio shows that there is no statistical effect of Auditors' culpability on creative accounting. The finding was in agreement with Gueninparacini and Gendron (2010) that auditors are the favourite whipping boy when a significant misstatement is publicly unveiled.

In response to the second hypothesis, the researcher undertook a study to observe whether or not there exist any statistical effects of reasons for statutory auditors engaging in creative accounting practices on the practice of creative accounting. The high F-statistics established that the reasons for statutory auditors engaging in creative accounting practices have effects on the practice of creative accounting. The finding was in line with Otusanya (2011) argument that auditors involvement in anti-social practices (creative accounting inclusive) was due to their pursuit of commercial interests. Equally, the finding revealed that real causes of creative accounting lie in the conflicts of interest among different interest groups. Managing shareholders' interest is to pay less tax and dividends. Investor-shareholders are interested to get more dividends and capital gains. Country's tax authorities would like to collect more and more taxes. Employees are interested to get better salary and higher profit share. Creative accounting puts one group or two to advantageous position at the expense of others.

\section{CONCLUSION AND RECOMMENDATIONS}

Based on the analyses of the study, the study concluded that auditors' culpability has no effect on creative accounting and other anti-social practices in Nigeria. The study recommends that accountants should uphold high ethical standards and maintain integrity in all their professional dealings. Accountants should not allow personal prejudice or bias to override the principle of objectivity, transparency and due diligence in the profession. Auditors must not 
only develop questioning mind, skill for critical assessment of audit evidence but must also exercise these skills with reasonable care and diligence.

\section{References}

Adeyemi, S. B. (2004). Minimisation of Financial crime - The Role of the Accountant. Student Accountant Journal, $1(2)$.

Akenbor, C. O., \& Ibanichuka, E.A.L (2012). Creative accounting practices in Nigerian Banks. African Research Review Journal, Ethiopia, 6(3).

Akin-ogundeji, O (2010): Taming corporate frauds. Advancing organizational Effectiveness through understanding and Taming corporate Frauds. Available on-line: info@odsynergy.com. Retrieved on 27/10/2019.

Alam, A.K.M (1988): Creative accounting- is it leading towards a stock market crash? The cost and Management. The Institute of Cost and Managements Accountants of Bangladesh, Dhaka, 6(5).

Aloba, A. (2002). Accountants aid Money Laundering. News World, November 1, 2002.

Aremu, J. A., \& Bello, M. (2004). Creative accounting and financial scandals. International Journal of Accountancy, $17(2)$.

Bakre, O. M. (2007). The Unethical Practices of Accountants and Auditors and the Compromising Stance of Professional Bodies in the Corporate World Evidence from Corporate Nigeria. Accounting Forum, 31(3).

Bakre, O.M (2008). Looting by the Ruling Elite, Multinational corporations and the Accountants. The genesis of indebtedness, poverty and underdevelopment in Nigeria. A paper presented at the 2008 University of Essex Tax Workshop, Essex Business School, University of Essex, UK, July, 2008.

Bolkaoui, A. R. (2004). Accounting Theory (5th ed.). Thompson Learn.

Dahdouh, H. (2006). The Responsibility of Auditors towards Detecting Fraudulent in the Financial Reports of Industrial Companies and the factors affecting this Detection. University of Damascus Journal, 22(1).

Guenin-Paracini, H. \& Gendron, Y. (2010). Auditors as modern pharmakoi. Legitimacy paradoxes and the production of Economic Order. Critical Perspectives on Accounting, 21(2).

Idris, A. A., Kehinde, J. S., Ajemunigbohun, S.S., \& Gabriel, J. S. (2012). The Nature, Techniques and Prevention of Creative accounting. Empirical Evidence from Nigeria. Canadian Journal of Accounting and Finance, 1(1).

Ijeoma, N., \& Aronu, C. O. (2013). The Contribution of Creative Accounting on Economic Development. International Journal of Scientific \& Engineering Research, 4 (9).

Marianne, O. (2006). Audit Independence. Its Importance to the External Auditor's Role in Banking Regulation and Supervision. Available on-line: http://mpra.ub.uni-muenchen.de/231/.Retrieved on 17/10/2019.

Matar, M., \& Al Halabi, L. (2009). The Role of External Auditors in Restricting the Effects of Creative Accounting on the Credibility of Financial Data Issued by the Jordanian Shareholding Companies. Master Thesis, Middle East University.

Moldovan, R., Achim, S., \& Avram, C. (2010). Fighting the Enemy of Fair View Principle-Getting to Know Creative Accounting. Steinke Economics. Journal of Economics and Management Science, 7(3).

Obazee, J. O. (2005). The Inspectorate Unit guidelines bridging the expectation gap. Paper presented at the one day consultative forum for key players and regulations in the Nigerian

Okike, E. (2004). Management of Crisis: The Response of the Auditing Profession in Nigeria to Challenge to its Legitimacy. Accounting, Auditing and Accountability Journal, 17(5).

Okoye, E. I., \& Alao, B. B. (2008). Creative Accounting in Financial Reporting. A Quarterly Journal of Association of National Accountants of Nigeria, 16(1).

Osisioma, B. C., \& Enahoro, J. A. (2006). Creative Accounting and Option of Total Quality Accounting in Nigeria. Journal of Global Accounting, 2(1).

Otusanya, J. O. (2011). The Role of Professionals in Anti-social Financial practices. The case of Nigeria.

Accountancy, Business and the Public Interest, 11(1).

Otusanya, O. J., \& Lauwo, S. (2010). The Role of Auditors in Nigerian Banking Crisis. Accountancy, Business and the Public Interest, 10(2). 
Rabin, C. E. (2003). Determinants of Auditors' Attitudes Towards Creative accounting. Meditari Accountancy Research, 13(2).Available on-line: http://dx.doi.org/10.1108/10222529200500013.. Retrieved on 17/10/2019.

Rosner, R. (2003). Theories of economic regulation' 5 Bell. Journal of Economics and Management Science, Vol. 8(2). Available on-line: http://dx.doi.org/10.2307/3003113. Retrieved on 7/10/2019. 